Notre Dame Law School

NDLScholarship

Journal Articles

Publications

2017

\title{
Utilizing Secondary Sanctions to Curtail the Financing of the Islamic State
}

Jimmy Gurule

Notre Dame Law School, jimmy.gurule.1@nd.edu

Follow this and additional works at: https://scholarship.law.nd.edu/law_faculty_scholarship

Part of the International Law Commons

\section{Recommended Citation}

Jimmy Gurule, Utilizing Secondary Sanctions to Curtail the Financing of the Islamic State, 18 Geo. J. Int'1 Aff. 36 (2017).

Available at: https://scholarship.law.nd.edu/law_faculty_scholarship/1281

This Article is brought to you for free and open access by the Publications at NDLScholarship. It has been accepted for inclusion in Journal Articles by an authorized administrator of NDLScholarship. For more information, please contact lawdr@nd.edu. 


\section{Business \&} Economics

\section{Utilizing} Secondary Sanctions to Curtail the Financing of the Islamic State

\author{
Jimmy Gurulé
}

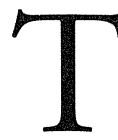

The Islamic State is the wealthiest terrorist organization in the world. ${ }^{1}$ It has an annual budget of over $\$ 2$ billion to finance its goal of establishing an Islamic or caliphate state. ${ }^{2}$ Flush with funds, it has acquired and controls large swaths of territory in Iraq and Syria, and has extended its reach into Afghanistan, Algeria, Egypt, Libya, the North Caucasus, northern Nigeria, Pakistan, the Philippines, Saudi Arabia, and Yemen. ${ }^{3}$

At the organizational level, the Islamic State needs money to recruit, train, and pay terrorist fighters. ${ }^{4}$ It also needs funding to purchase vehicles, weapons, ammunition, equipment, and explosives. The Islamic State exploits social media-most notoriously Twitter - to disseminate its propaganda across the globe in order to recruit and radicalize new followers. A recent report published by the Brookings Institution states that by virtue of its large number of supporters and highly organized tactics, the Islamic State

has been able to exert an outsized impact on how the world perceives it, by disseminating images of graphic violence (including the beheading of Western journalists and aid workers and more recently, the immolation of a Jordanian pilot), while using social media to attract new recruits and inspire lone actor attacks. ${ }^{5}$

According to the report, the number of Twitter accounts used by supporters of the Islamic State between September 2014 and December 2014 is conservatively estimated at $46,000 .{ }^{6}$ In short, the Islamic State needs money to sustain its global social media campaign and finance other terrorist-related activities.

Unfortunately, the US government's efforts to curtail the funding of the Islamic State have been largely ineffective. The government must adapt to the terrorist financing challenges posed by the Islamic State. More specifically, it should impose secondary economic sanctions on foreign companies that enable the Islamic State to refine and sell oil on the black market, rather than merely impose primary sanctions that prohibit US persons from doing business with the terrorist organization and require US banks to freeze terrorist-related assets located in the United States. While the international community may claim that imposing US sanctions on foreign entities operating abroad violates principles of foreign sovereignty, such extraterritorial sanctions are lawful under international law.

This article will discuss existing legislation used to curtail the financing of the Islamic State, the value of imposing secondary

Jimmy Gurulé is Professor of Law at Notre Dame Law School. He is a renowned expert on terrorism, terrorist financing, and anti-money laundering legislation and frequently provides his expertise to lawmakers on the House Judiciary Committee. 
sanctions against the terrorist group, and concerns regarding the extraterritorial application of US sanctions.

\section{Adapting to the Terrorist Financing Challenges Posed by the Islamic State}

Shortly after the terrorist attacks on September 11, 2001, President George W. Bush signed Executive Order 13224 (E.O. 13224), invoking his congressional grant of authority under the International Emergency Economic Powers Act. ${ }^{7}$ E.O. 13224 declared a national emergency with respect to "grave acts of terrorism and threats of terrorism committed by foreign terrorists, including the terrorist attacks ... committed on September 11, 2001 ... and the continuing and immediate threat of further attacks on United States nationals or the United States." 8

E.O. 13224 authorizes the Secretary of the Treasury, in consultation with the Secretary of State and Attorney General, to designate foreign persons and entities as Specially Designated Global Terrorists (SDGTs) who (1) "act for or on behalf of" or are "owned or controlled by" an SDGT; (2) "assist in, sponsor, or provide financial, material, or technological support for, or financial or other services to" SDGTs; or (3) are "otherwise associated with" SDGTs.? Further, E.O. 13224 authorizes the Secretary of State, in consultation with the Secretary of the Treasury and Attorney General, to designate as SDGTs persons determined "to have committed, or to pose a significant risk of committing, acts of terrorism that threaten the security of United States nationals or the national security, foreign policy, or economy of the United States." ${ }^{\prime 0}$

The Treasury Department's Office of Foreign Assets Control (OFAC) is the lead agency responsible for implementing E.O.
13224. ${ }^{11}$ In coordination with the Department of State and Department of Justice, OFAC identifies persons and entities for designation as SDGTs and targets of asset freezes. ${ }^{12}$ Blocking terrorist-related assets is an administrative, rather than a criminal, action. As such, the designation does not require that the party be criminally prosecuted or even charged with committing acts of terrorism. Because SDGT designations are administrative in nature, the government is not required to satisfy the criminal standard of proof beyond a reasonable doubt. Instead, an individual may be designated an SDGT and his assets frozen if there is "reason to believe" that he may have engaged in activities that violate E.O. $13224 .{ }^{13}$ Once a designation is made pursuant to E.O. 13224, OFAC provides notice of blocking actions by issuing press releases, by updating its webpage, and by publishing a notice in the Federal Register. ${ }^{14}$

\section{Blocking terrorist-related assets is an administrative, rather than a criminal, action.}

Designation as an SDGT has several important legal consequences. First, all property and interests in property of SDGTs that is located in the United States must be blocked. ${ }^{15}$ Second, US persons are prohibited from entering into any transaction with or otherwise dealing in such blocked property. ${ }^{16}$ Specifically, E.O. $13224 \$ 2(\mathrm{~A})$ prohibits any US person from "making or receiving ... any contribution of funds, goods, or services to or for the benefit of" SDGTs. Third, severe civil and criminal penalties may be assessed for violating E.O. 13224. ${ }^{17}$ Ultimately, the purpose of E.O. 13224 is to isolate these designated terrorists and their sponsors from the US financial system and prevent their assets that are 
subject to US jurisdiction from being used to finance future attacks.

Initially, E.O. 13224 designated twelve individuals and fifteen entities identified in its Annex as SDGTs. ${ }^{18}$ To date, the number of SDGTs has grown to approximately 1,000 individuals and entities. ${ }^{19}$ E.O. 13224 has been the centerpiece of the US government's efforts to deprive al-Qaeda and other terrorist organizations of funding. Most recently, E.O. 13224 has been used against the Islamic State.

E.O. 13224 has been an effective tool in stemming the flow of funds to al-Qaeda, which largely relies on support from external donors and corrupt charities that often have assets in the United States subject to blocking. However, the Islamic State poses a different terrorist financing challenge. Unlike, al-Qaeda, the Islamic State is primarily self-funded. It obtains the vast majority of its revenue from (1) oil and gas sales, (2) extortion and taxation, (3) kidnapping for ransom, (4) looting banks, (5) selling stolen antiquities, and (6) human traffickingthat is, selling young girls and women as sex slaves. ${ }^{20}$ Despite recent military air strikes aimed at destroying the infrastructure used by the Islamic State to pump Syrian oil and the recent decline in global oil prices, the terror group continues to generate as much as $\$ 200$ to $\$ 500$ million a year from the sale of oil..$^{21}$

As stated by Daniel Glaser, Assistant Secretary for Terrorist Financing, the Islamic State "derive[s] so much of [its] resources internally, that more traditional counterterror finance tools we would apply, say in the case of al-Qaeda, to cut off a terror organization from its income sources are not applicable in this case." 22 Despite the fundamental differences between how these two terrorist organizations are funded, Treasury and State Department officials continue to apply E.O. 13224 against the Islamic State, designating its leaders, fighters, and recruiters as SDGTs. ${ }^{23}$ Unfortunately, targeting Abu Bakr al-Baghdadi, the leader of the Islamic State, and its other senior leaders under E.O.13224 has limited practical value. Senior members of the Islamic State have no assets located in the United States subject to blocking under E.O.13224, nor is there any evidence that US persons are doing business with these designated individuals.

\section{Utilizing Secondary Sanctions against Foreign Individuals and Entities}

The US government must adapt to the terrorist-financing challenges posed by the Islamic State and refocus its efforts. A good model is the secondary economic sanctions regime imposed against Iran. "Ordinarily, when the United States imposes economic sanctions, it imposes primary sanctions only - to restrict its own companies and citizens (or other people who are in the United States) from doing business with a rogue regime, terrorist group, or other international pariah." ${ }^{24}$ Secondary sanctions, however, "involve additional economic restrictions designed to inhibit non-US citizens and companies abroad from doing business with a target of primary US sanctions." 25

The US government must adapt to the terrorist-financing challenges posed by the Islamic State and refocus its efforts.

Congress should enact legislation against the Islamic State similar to the Comprehensive Iran Sanctions, Accountability, and Divestment Act of 2010 (CISADA), which imposed secondary sanctions on foreign companies doing business with Iran. ${ }^{26}$ The CISADA forced foreign firms to choose between participating in the US commercial market and engaging in energy-related 
transactions with Iran. Before the passage of CISADA, US persons were prohibited from conducting business with Iran. CISADA expanded the scope of prohibited activities to include efforts by foreign companies to (1) sell, lease, or provide to Iran any goods, services, technology, information, or support that would allow Iran to maintain or expand its petroleum refineries and (2) to supply refined petroleum products to Iran. ${ }^{27}$ CISADA also sanctioned any activity that "directly and significantly" assists Iran in either developing its oil-refining capacity or obtaining refined petroleum..$^{28}$

When a foreign company violates CISADA, the President must impose at least three different types of economic sanctions against the violating company. CISADA also expanded the list of available sanctions, previously authorized by the Iran Sanctions Act, from six to nine. ${ }^{29}$ The newly added sanctions include prohibitions against (1) foreign exchange transactions subject to US jurisdiction; (2) transfers of credit or payment between, by, through, or to financial institutions subject to US jurisdiction; and (3) transactions or exercise of any right, power, or privilege with respect to property subject to US jurisdiction. ${ }^{30}$

Legislation similar to CISADA should be enacted by Congress to authorize the imposition of secondary economic sanctions against any foreign firms contributing to the maintenance and development of the Islamic State's oil and gas infrastructure. While US military air strikes have damaged oil refineries in Syria, significantly reducing the Islamic State's income from the sale of Syrian oil, the terror group should be prevented from repairing and rebuilding these damaged oil facilities with the assistance of foreign firms. To this end, secondary sanctions should be statutorily imposed on any foreign entity assisting the Islamic State in these repair efforts by selling parts or providing technological support or services. Economic sanctions should also be imposed on foreign companies transporting oil from territories controlled by the Islamic State in Syria and Iraq, as well as foreign entities purchasing such oil.

If any of the foreign companies contributing to the Islamic State's energy sector are conducting business with the United States, the imposition of secondary sanctions could be costly. The economic sanctions could substantially exceed the profits generated by these companies for assisting the Islamic State in maintaining its oil refineries and distributing Syrian and Iraqi oil on the black market.

E.O. 13224 has limited application to foreign companies doing business with the Islamic State. The use of secondary sanctions, on the other hand, would directly punish these foreign firms and deter them from providing services, equipment, and technology to the terrorist group to refine, distribute, and sell stolen Syrian oil and generate enormous profits. Under $\$ 1(\mathrm{~d})(\mathrm{i})$ of E.O. 13224, US persons are prohibited from "provid[ing] financial, material, or technological support for or financial or other services to or in support of" SDGTs. The Islamic State has been designated an SDGT. ${ }^{31}$ While US persons are prohibited from engaging in commercial transactions with the Islamic State, E.O. 13224 does not apply to foreign firms. The sanctions available under E.O. 13224 would apply only if the foreign entities assisting the Islamic State were designated as SDGTs and had property in the United States subject to blocking.

The legislation being proposed in this article would allow secondary sanctions beyond what is currently permitted under E.O. 13224. Regardless of whether a foreign firm holds property within the United States or is designated as an SDGT, if the foreign entity does business with the Islamic State it would be subject to a wide array of economic 
sanctions similar to those authorized against foreign businesses assisting Iran in developing its oil-refining capacity. Furthermore, a CISADA-type of legislation would provide the president with a more nuanced set of punitive measures for sanctioning those foreign enterprises doing business with the Islamic State.

\section{The Extraterritorial Application of US Economic Sanctions}

Secondary sanctions imposed by the United States have proved highly controversial "because of broad claims that they are illegally 'extraterritorial' in purpose and effect." ${ }^{32}$ However, the law of nations permits the exercise of extraterritorial jurisdiction under five general principles: territorial, national, protective, universality, and passive personality. ${ }^{33}$ The Restatement (Third) of Foreign Relations Law recognizes four principles of extraterritorial jurisdiction: (1) the "territorial principle" - when conduct takes place in, or is intended to have effects within, the territorial borders of the country; $3^{34}(2)$ the "nationality principle"-jurisdiction when the perpetrator is a national of the asserting country; 35 (3) the "protective principle"-jurisdiction when acts are directed at the integrity or national security of the asserting country's government; ${ }^{36}$ and (4) the "universal principle"-jurisdiction over enumerated crimes so heinous that they are universally condemned by all nations. ${ }^{37}$ The "passive personality principle," which allows jurisdiction over conduct committed abroad against the asserting state's citizens, is not officially recognized by the Restatement, but has found increasing support in the international community.

The protective principle permits the imposition of economic sanctions against foreign firms helping the Islamic State sustain, rebuild, or develop its oil infrastructure.
Under the protective principle, jurisdiction is based on whether the national interest or national security of the asserting country is threatened or injured by conduct outside that nation's territory. ${ }^{38}$ The United States may exercise extraterritorial jurisdiction when the conduct of such foreign entities "has a potentially adverse effect upon the security and governmental functions of the nation." 39

The Islamic State derives substantial revenues from the sale of oil pumped in Syria and Iraq. Those funds finance its sophisticated global media campaign used to inspire lone wolf terrorist attacks, including attacks in the United States. Foreign firms that provide material support to the Islamic State to rebuild and maintain its oil infrastructure indirectly threaten US national security. The imposition of secondary sanctions against such foreign companies is therefore justified under principles of international law.

\section{Foreign firms that provide material support to the Islamic State to rebuild and maintain its oil infrastructure indirectly threaten US national security.}

\section{Conclusion}

The US government's use of E.O. 13224 to reduce the financing of the Islamic State has been largely ineffective. Members of the terrorist organization do not possess property located in the United States subject to blocking, and US persons do not conduct business with such individuals. The SDGT designation process merely results in publicly identifying members of the Islamic State and placing their names on the Treasury Department's "name and shame" list, with little practical consequences. Imposing 
secondary sanctions on foreign companies that contribute to developing and maintaining the Islamic State's oil infrastructure is a much more promising strategy to reduce the financing of the wealthiest terrorist organization in history. The imposition of secondary sanctions further conveys the message that foreign firms doing business with the Islamic State are indirectly facilitating the funding of the Islamic State and threatening international peace and security.

\section{Notes}

1. See Jose Pagliery, "Inside the \$2 Billion ISIS War Machine," CNN, December 11, 2015, http://money.cnn.com/2015/12/06/news /isis-funding/ ("The Islamic State is certainly the best financially endowed terrorist organization in history.").

2. See David S. Cohen, Treasury Under Secretary for Terrorism and Fin. Intelligence, Remarks at the Carnegie Endowment for Int'l Peace, "Attacking ISIL's Financial Foundation," October 23, 2014, http://www.treasury.gov /press-center/press-releases-Pages/j;2672 .aspx; see also Pagliery, "Inside the $\$ 2$ Billion ISIS War Machine."

3. See Dep't of State, Country Reports on Terrorism 2015, 373-75, http://www.state.gov /documents/organization/258249.pdf; see also Terrorism in Africa: The Imminent Threat to the United States: Hearing Before Subcomm. on Counterterrorism and Intelligence of the H. Comm. on Homeland Sec., 114th Cong. 3 , 7 (2015) (statement of Daniel L. Byman, Research Director, Center for Middle East Policy); Randy Fabi and Manuel Mogato, "Southeast Asian Islamic State Unit Being Formed in Southern Philippines," Reuters, June 23, 2016, http://ww.reuters.com/article/us-phillippines -militants-idUSKCN0Z91C5?utm-source.

4 . It is estimated that the Islamic State has between 20,000 and 32,000 fighters in Syria and Iraq. See Carla E. Humud, Robert Pirog, and Liana Rosen, Islamic State Financing and U.S. Policy Approaches, Washington, DC: Congressional Research Service, April 10, 2015, 2.
5. J. M. Berger and Jonathon Morgan, The ISIS Twitter Census: Defining and Describing the Population of ISIS Supporters on Twitter, Washington, DC: Brookings, March 2015, 2.

6. Ibid.

7. International Emergency Economic Powers Act, 50 U.S.C. $\$ \$ 1701$ et seq. (2012).

8. Exec. Order No. 13224, 3 C.F.R. $\$ 786$ (2001), reprinted as amended in 50 U.S.C. $\$ 1701$ note (Supp. IV 2004) [hereinafter "E.O. 13224"].

9. Ibid. at $\$ 1$ (c)-(d)(i)-(ii).

10. Ibid. at $\$ 1$ (b).

11. See Dep't of Treasury, Office of Foreign Assets Control, Terrorist Assets Report, 2014, 2 , https://www.treasury.gov/resource-center /sanctions/Programs/Documents/tar2014.pdf.

12. See E.O. 13224, at $₫ 1$.

13. See Al Haramain Found. v. United States Department of Treasury, 2009 WL 3756363 , *14 (D. Or.) ("Such a standard is appropriate in cases of this kind, especially since ' $[t]$ he standard of probable cause is particularly related to criminal investigations, not routine, non-criminal procedures."); Al Haramain Islamic Found. v. United States Dept. of Treasury, 585 F. Supp.2d 1233, 1253 (D. Or. 2008) ("Contrary to AHIF-Oregon's contention, the government need not show AHIF-Oregon intended to support terrorism, merely that OFAC held a reasonable belief that AHIF-Oregon is a component of a larger organization that funds terrorism.").

14. See Al-Aqeel v. Paulson, 568 F. Supp.2d 64, 71 (D.D.C. 2008) (OFAC posted press release announcing designation on the Treasury Department website, which provided adequate notice of plaintiffs designation).

15. E.O. 13224 , at $\$ 1$.

16. Ibid. at $\$ 2(a)$.

17. A maximum civil penalty of $\$ 50,000$ may be imposed for each violation of E.O. 13224. 31 C.F.R. $\$ 594.701(a)(1)$. Further, a person who "willfully" violates the order may be sentenced to a term of imprisonment not exceeding twenty years, assessed a fine of $\$ 50,000$, or both. Ibid. $\$ 594.701(\mathrm{a})(2)$.

18. See E.O. 13224, Annex.

19. See Dep't of Treasury, Terrorist Assets Report, 6. 
20. See Cohen, "Attacking ISIL's Financial Foundation," 2-3.

21. See ibid.; see also Patrick Wintour, "Oil Revenue Collapse Means ISIS Reliant on Gulf Funds, Inquiry Hears," The Guardian, March 8, 2016, http://gu.com/p/4hctg/sbl (claiming that military attacks on oil infrastructure, falling global oil prices, and the low quality of Syrian oil have reduced annual oil revenues to $\$ 200$ million); Hamza Hendawi and Qassim Abdul-Zahra, "ISIS Is Making up to $\$ 50$ million a Month from Oil Sales," Business Insider, October 23, 2015, http://www.businessin sider.com/isis-making-50-million-a-month -from-oil-sales-2015-10.

22. Mathew Rosenberg, Nicholas Kulish, and Steven Lee Myers, "Predatory Islamic State Wrings Money from Those It Rules," New York Times, November 29, 2015, http://ny times/1Op4fa.

23. See, e.g., Press Release, Dep't of Treasury, "Treasury Sanctions Key ISIL Leaders and Facilitators Including a Senior Oil Official" February 11, 2016, https://www.treasury .gov/press-center/press-releases/Pages /j10351.aspx; Press Release, Dep't of Treasury, "Treasury Sanctions Major Islamic State of Iraq and the Levant Leaders, Financial Figures, and Supporters," September 29, 2015, https://www.treury.gov/press-center-releases /Pages/j10188.aspx; Press Release, Dep't of Treasury, "Treasury Designates Twelve Foreign Terrorist Fighter Facilitators," September 24, 2014, https://www.treasury.gov/press -center/press-releases/Pages/j1265l.aspx; Press Release, Dep't of State, "Terrorist Designation of Salah Abdeslam,” April 5, 2016, http:// www.state.gov/r/pa/prs/ps/2016/04/255500 .htm (designating operative of the Islamic State allegedly involved in the November 13, 2015, Paris attacks); Press Release, Dep't of State, "Designation of Foreign Terrorist Fighters," September 29, 2015, http://www.state .gov/r/pa/prs/ps/2015/09/247433.htm.

24. Jeffrey A. Meyer, "Second Thoughts on Secondary Sanctions," University of Pennsylvania Journal of International Law 30 (2014): 905.
25. Ibid.

26. Comprehensive Iran Sanctions, Accountability, and Divestment Act of 2010, Pub. L. No. 111-195, 124 Stat. 1312 (codified at 22 U.S.C. $\$ 8501$ note $(2010))$.

27. See ibid. $\$ 102$.

28. Ibid.

29. Ibid. $\$ 102(b)$; see also Iran and Libya Sanctions Act of 1996 (renamed the Iran Sanctions Act of 1996), Pub. L. No. 104-172, 110 Stat. 1541, as amended by Pub. L. No. 111-195, \$102, 124 Stat. 1312, 1317-28.

30. CISADA $\$ 102(b)(2)$. Before the CISADA, the President could choose from among six sanctions to impose on foreign entities: denial of Export-Import Bank assistance for exports; denial of export licenses or other specific requests under US export control; denial of loans exceeding $\$ 10$ million from US financial institutions in any twelve-month period; prohibition on sanctioned financial institutions from designation as a primary dealer in US debt or as a repository for US government funds; ban on procurement contracts with the US government; and case-by-case imposition of import restrictions.

31. The Islamic State was designated as an SDGT on September 29, 2015. See Dep't of Treasury, Individuals and Entities Designated by the State Department Under E.O. 13224, available at http://www.state.gov/j/ct/rls /other/des/143210.htm (last visited June 29, 2016).

32. Meyer, "Second Thoughts on Secondary Sanctions," 905.

33. See Restatement (Third) of Foreign Relations Law $\$ 402 \mathrm{cmt}$.

34. Ibid. $\$ 401(1)(a),(1)(b)$.

35. Ibid. $\$$ 402(2) comment (e) and Reporter's Note 1.

36. Ibid. $\$ 402(3)$ comment (f).

37. Ibid. $\$ 404$.

38. See United States v. Yousef, 327 F.3d 56, 91 n.24 (2d Cir. 2013); United States v. Felix-Gutierrez, 940 F.2d 1200, 1204 (9th Cir. 1991).

39. United States v. Benitez, 741 F.2d 1312, 1316 (11th Cir. 1984). 